\title{
Dopamine Activates Noradrenergic Receptors in the Preoptic Area
}

\author{
C. A. Cornil, ${ }^{1}$ J. Balthazart, ${ }^{1}$ P. Motte, ${ }^{3}$ L. Massotte, ${ }^{2}$ and V. Seutin ${ }^{2}$ \\ Center for Cellular and Molecular Neurobiology, ${ }^{1}$ Research Group in Behavioral Neuroendocrinology and ${ }^{2}$ Laboratory of \\ Pharmacology, and ${ }^{3}$ Department of Life Sciences, Laboratory of Plant Cellular Biology, University of Liège, B-4020 \\ Liège, Belgium
}

Dopamine (DA) facilitates male sexual behavior and modulates aromatase activity in the quail preoptic area (POA). Aromatase neurons in the POA receive dopaminergic inputs, but the anatomical substrate that mediates the behavioral and endocrine effects of DA is poorly understood. Intracellular recordings showed that $100 \mu \mathrm{M}$ DA hyperpolarizes most neurons in the medial preoptic nucleus $(80 \%)$ by a direct effect, but depolarizes a few others (10\%). DA-induced hyperpolarizations were not blocked by D1 or D2 antagonists $(\mathrm{SCH}-23390$ and sulpiride). Extracellular recordings confirmed that DA inhibits the firing of most cells (52\%) but excites a few others (24\%). These effects also were not affected by DA antagonists $(\mathrm{SCH}-$ 23390 and sulpiride) but were blocked by $\alpha_{2}$-(yohimbine) and $\alpha_{1}$-(prazosin) noradrenergic receptor antagonists, respectively. Two dopamine- $\beta$-hydroxylase (DBH) inhibitors (cysteine and fusaric acid) did not block the DA-induced effects, indicating that DA is not converted into norepinephrine (NE) to produce its effects. The $\mathrm{pK}_{\mathrm{B}}$ of yohimbine for the receptor involved in the DA- and NE-induced inhibitions was similar, indicating that the two monoamines interact with the same receptor. Together, these results demonstrate that the effects of DA in the POA are mediated mostly by the activation of $\alpha_{2}$ (inhibition) and $\alpha_{1}$ (excitation) adrenoreceptors. This may explain why DA affects the expression of male sexual behavior through its action in the POA, which contains high densities of $\alpha_{2}$-noradrenergic but limited amounts of DA receptors. This study thus clearly demonstrates the existence of a cross talk within CNS catecholaminergic systems between a neurotransmitter and heterologous receptors.

Key words: preoptic area; dopamine; noradrenergic receptors; extracellular recording; intracellular recording; quail
Dopaminergic (DA) systems have been the focus of much research, primarily because alterations in DA neurotransmission result in major diseases such as Parkinson's disease and schizophrenia. DA is also implicated in the control of various brain functions, e.g., locomotion, cognition, and reproduction (Jackson and Westlind-Danielsson, 1994; Jaber et al., 1996). In mammals, DA, acting in part at the level of the preoptic area (POA) through both D1- and D2-like receptor subtypes, facilitates male sexual behavior (Bitran and Hull, 1987; Blackburn et al., 1992; Meisel and Sachs, 1994; Hull et al., 1995, 1997). Similar effects of DA on male sexual behavior have been observed in quail (Absil et al., 1994; Balthazart et al., 1997; Castagna et al., 1997), a widely used model in behavioral neuroendocrinology (Balthazart and Ball, 1998a) that displays high levels of DA and tyrosine hydroxylase (TH), the rate-limiting enzyme in DA synthesis, in the POA (Ottinger and Balthazart, 1987; Balthazart et al., 1992; Bailhache and Balthazart, 1993).

In quail, the sexually dimorphic medial preoptic nucleus (POM) represents a necessary and sufficient site of steroid action for the activation of male copulatory behavior (Panzica et al., 1996). The POM is outlined by a group of cells expressing the

Received July 8, 2002; revised Aug. 20, 2002; accepted Aug. 22, 2002.

This work was supported by grants from the National Institutes of Health (MH50388) and the Belgian Fonds de la Recherche Fondamentale Collective (FRFC) (2.4555.01) to J.B., the French Community of Belgium (ARC99/04-241) to J.B. and V.S., and the Belgian FRFC (2.4542.00) and the Fonds Spéciaux pour la Recherche to P.M. C.A.C. is an FNRS Research Fellow.

Correspondence should be addressed to Charlotte Cornil, Center for Cellular and Molecular Neurobiology, Research Group in Behavioral Neuroendocrinology, University of Liège, 17 Place Delcour (Bat L1), B-4020 Liège, Belgium. E-mail: Charlotte.Cornil@ulg.ac.be.

Copyright (c) 2002 Society for Neuroscience $0270-6474 / 02 / 229320-11 \$ 15.00 / 0$ enzyme aromatase (Foidart et al., 1995), which catalyzes the transformation of testosterone into estradiol, a critical step in the activation of male behavior (Balthazart and Ball, 1998b). The POM receives inputs from various dopaminergic and noradrenergic areas (Balthazart and Absil, 1997), and TH-immunoreactive fibers are found in close association with aromatase-immunoreactive cells (Balthazart et al., 1998), suggesting functional interactions. Accordingly, in vitro studies indicate that DA can rapidly affect the preoptic aromatase activity (Baillien and Balthazart, 1997; Balthazart et al., 2002). Thus it has been hypothesized that DA affects male sexual behavior in part through the control of aromatase activity (Absil et al., 2001b; Balthazart et al., 2002). However, the anatomical substrate and cellular mechanisms that mediate behavioral and endocrine effects of DA are poorly understood.

We demonstrate here that DA affects the electrical activity of most preoptic neurons. DA hyperpolarizes the majority of these neurons, which markedly decreases their firing rate, but an opposite effect is seen in a few cells. Pharmacological experiments provide converging evidence demonstrating that these effects are not mediated by interactions of DA with dopaminergic receptors but rather by the activation of $\alpha_{2^{-}}$(inhibition) or $\alpha_{1}$ - (excitation) noradrenergic receptors. These data extend a previous report indicating that the central effects of DA are mediated in part by noradrenergic receptors (Malenka and Nicoll, 1986). They fit in well with the presence of very high densities of $\alpha_{2}$-noradrenergic receptors in the quail POM and may help to explain why DA affects male sexual behavior even though DA receptors are scarce in the POA. More generally, they suggest that in disorders such as schizophrenia, in which hyperactivity of some DA pathways has been demonstrated (Laruelle and Abi-Dargham, 1999; Meyer- 
Lindenberg et al., 2002), excessive stimulation of noradrenergic receptors by DA might be observed in some brain areas.

\section{MATERIALS AND METHODS}

\section{Animals}

All experiments were performed on sexually mature male Japanese quail (Coturnix japonica) obtained from a local breeder at the age of 3-6 weeks (G. Franckart, Falmignoul, Belgium). Throughout their life at the breeding colony and in the laboratory, birds were exposed to a photoperiod simulating long days ( $16 \mathrm{hr}$ light and $8 \mathrm{hr}$ dark per day) and had food and water available ad libitum. All experimental procedures were in agreement with Belgian laws on the "Protection and Welfare of Animals" and the "Protection of Experimental Animals" and the International Guiding Principles for Biomedical Research Involving Animals published by the Council for International Organizations of Medical Sciences. The protocols were approved by the Ethics Committee for the Use of Animals at the University of Liège.

\section{Electrophysiological recordings}

Animals were killed by decapitation, and brains were rapidly dissected out of the skulls and put in chilled $\left(2-4^{\circ} \mathrm{C}\right)$ artificial CSF (ACSF) of the following composition (in $\mathrm{mM}$ ): $130 \mathrm{NaCl}, 2.5 \mathrm{KCl}$ (intracellular experiments) or $5 \mathrm{KCl}$ (extracellular experiments), $1.2 \mathrm{NaH}_{2} \mathrm{PO}_{4}, 1.2 \mathrm{MgCl}_{2}$, $2 \mathrm{CaCl}_{2}, 10$ glucose, and $20 \mathrm{NaHCO}_{3}$, saturated with $95 \% \mathrm{O}_{2}-5 \% \mathrm{CO}_{2}$, $\mathrm{pH} 7.4$.

Coronal $300-\mu \mathrm{m}$-thick slices containing the medial part of the POA at the level of the POM were prepared in cold $\left(2-4^{\circ} \mathrm{C}\right)$ ACSF using a vibratome and transferred to a small beaker containing ACSF at $32^{\circ} \mathrm{C}$. A few minutes later, slices were transferred into a recording chamber (volume $\pm 0.5 \mathrm{ml}$ ) where they were completely submerged in ACSF at $34.5 \pm 0.5^{\circ} \mathrm{C}$ flowing at a rate of $2.5 \pm 0.5 \mathrm{ml} / \mathrm{min}$. The tissue was stabilized by an electronic microscope grid and small platinum weights.

Microelectrodes were positioned in the caudal part of the POM under visual guidance using an MHW-3 Narishige micromanipulator (Narishige) and a dissection microscope (Olympus Optical). The POM was identified as the periventricular area located ventrally to the anterior commissure, which can be easily distinguished in fresh brain sections.

Intracellular recordings in the bridge balance mode were made using borosilicate microelectrodes (resistance, 100-150 M $\Omega$ ) prepared on a Sutter P97 puller (Sutter Instruments, Novato, CA) and filled with $2 \mathrm{M}$ $\mathrm{KCl}$ or $2 \mathrm{M} \mathrm{K}$-acetate. Some microelectrodes were filled with $2 \mathrm{M}$ $\mathrm{K}$-acetate $+0.5 \%$ biocytin (Sigma, St. Louis, MO) to visualize the recorded neurons. Membrane potentials were recorded with a SEC0-1L amplifier (npi, Tamm, Germany). Electrical signals were filtered at $1 \mathrm{kHz}$ and recorded on-line using a paper chart recorder (model TA240, Gould Instruments, $\mathrm{OH}$ ). Some traces were also stored on a Fluke oscilloscope and subsequently transferred on a computer. Off-line analysis was performed using the Flukeview 2.0 software (Fluke Corporation, Everett, WA). During intracellular experiments, the spontaneous firing and synaptic communication were inhibited by exposure to $0.5-1 \mu \mathrm{M}$ tetrodotoxin (TTX), which blocks fast sodium channels.

Extracellular recordings were performed using conventional methods (Seutin et al., 1990). Briefly, borosilicate microelectrodes were prepared on a Narishige puller and filled with ACSF (tip resistance 5-8 M $\Omega$ ). Signals were amplified 1000 times with a homemade amplifier. Action potentials were selected with a window discriminator, and the number of spikes during successive $10 \mathrm{sec}$ periods was recorded with a homemade cumulative digital counter. These counts were averaged over successive 1 min blocks. Action potentials were also digitized and stored on a hard disk using Spike 2 software (Cambridge Electronic Design, Cambridge, UK). This software was also used for off-line analysis.

All drugs were applied by superfusion at known concentrations using three-way taps. Each concentration was applied for at least 5 min to ensure that the drug concentration reached equilibrium in the tissue. When antagonists or inhibitors of DBH were used, they were first superfused alone for at least $10 \mathrm{~min}$. All extracellular experiments were made in the presence of (3-aminopropyl) (diethoxymethyl) phosphinic acid (CGP-35348) $(30 \mu \mathrm{M})$, SR-95531 $(10 \mu \mathrm{M})$, 6-cyano-7-nitroquinoxaline-2,3-dione (CNQX) (10 $\mu \mathrm{M})$, and MK-801 (10 M), to block $\mathrm{GABA}_{\mathrm{B}}, \mathrm{GABA}_{\mathrm{A}}$, AMPA-kainate, and NMDA receptors, respectively. We have shown previously that such an ACSF blocks all synaptic potentials in these cells (Cornil et al., 2001). This solution will subsequently be referred to as "synaptic blockers." In these conditions, synaptic transmission should be blocked, therefore ensuring that the observed effects of the dopaminergic and noradrenergic compounds result from a direct action on the neuron that is studied.

\section{Experimental protocols}

Selection of dopamine/norepinephrine concentrations tested. For intracellular recordings, a concentration of $100 \mu \mathrm{M}$ DA was used. For extracellular recordings, DA was originally applied first at a concentration of 10 $\mu \mathrm{M}$ that was secondarily increased if cells did not respond. Because most neurons responded to $30 \mu \mathrm{M} \mathrm{DA}$, this concentration was then preferentially used for the first bath application of DA. However, when $30 \mu \mathrm{M}$ DA had no detectable effect or effects that were too small in magnitude to be considered reliable (see below), the concentration was increased to ensure that the cell was indeed nonresponsive. The same procedure was used for norepinephrine (NE).

$E C_{50}$ determination. The concentrations of DA or NE producing $50 \%$ of the maximal inhibitory effect $\left(\mathrm{EC}_{50}\right)$ on the firing rate were determined by testing the effects of three to five increasing concentrations of the amines in the range of $1-500 \mu \mathrm{M}$ for DA and $40 \mathrm{nM}-100 \mu \mathrm{M}$ for NE. The $\mathrm{EC}_{50}$ was then determined with the equation $\mathrm{E}=E_{\mathrm{MAx}} /\left(1+\left[\mathrm{EC}_{50} /\right.\right.$ $x]^{\mathrm{h}}$ ), where $x$ is the concentration of amine and $h$ is the Hill coefficient. In our experiments, most Hill coefficients were found to lie between 1 and 2; they were not considered further. $E_{\mathrm{MAx}}$ could usually be observed only for inhibitory effects and consisted of a $100 \%$ inhibition of firing. $\mathrm{EC}_{50}$ could usually not be determined for excitatory effects either because of the progressive desensitization of receptors after exposure to increasing concentrations of the amines or because the effect never saturated.

$p K_{B}$ determination. To positively identify the type of receptor mediating the inhibition of the firing rate in neurons exposed to DA or NE, we also measured the ability of yohimbine (an $\alpha_{2}$ antagonist) to displace the concentration-response curve of DA and NE. For this purpose, neurons were exposed to four to six increasing concentrations of DA (range, 3 $\mu \mathrm{M}-3 \mathrm{mM}$ ) or $\mathrm{NE}$ (range, $40 \mathrm{nM}-100 \mu \mathrm{M}$ ) in the absence and then subsequently in the presence of $30 \mathrm{~nm}$ yohimbine. This concentration of antagonist was found in preliminary experiments to provide an effect that was significant but also compatible with the use of reasonable concentrations of agonists. The $\mathrm{pK}_{\mathrm{B}}$ of yohimbine was then calculated using the Schild equation: $r-1=[B] / K_{\mathrm{B}}$, where $r$ is the concentration ratio between the $\mathrm{EC}_{50}$ of the agonist in the presence and absence of the antagonist and $B$ is the concentration of the competitive antagonist (Kenakin, 1984; Jenkinson et al., 1995). The $\mathrm{pK}_{\mathrm{B}}$ reflects the affinity of a competitive antagonist for its receptor in a bioassay. $\mathrm{A} \mathrm{pK}_{\mathrm{B}}$ value of an antagonist is usually within the same range as its $\mathrm{pK}_{\mathrm{i}}$ values in a binding experiment.

A limited desensitization to the effect of agonists was observed in a few neurons. The $\mathrm{pK}_{\mathrm{B}}$ experiments therefore were performed exclusively with cells that exhibited no significant desensitization $(<10 \%$ decrease of the maximal effect at any drug concentration over the $10-15 \mathrm{~min}$ period of superfusion). Although high levels of inhibition ( $80 \%$ or higher) were induced in these experiments, the complete blockade of firing was not always induced to avoid the risk of receptor desensitization. The expected data at both ends of the curve ( 0 and $100 \%$ effect) were added, however, to the experimental data to force the curve fitting software (GraphPad Prism 3.00, GraphPad Software, San Diego, CA) to calculate a regression curve using these theoretical values.

\section{Drugs}

Dopamine hydrochloride, fusaric acid (5-butylpicolinic acid), L-cysteine, norepinephrine (bitartrate salt), prazosin, SCH-23390, SKF-38393, TTX, and yohimbine were all obtained from Sigma (St. Louis). CNQX, MK-801 (dizocilpine), and quinpirole were obtained from Tocris (Bristol, UK). CGP35348, SR-95531 (2-[carboxy-3'-propyl]-3-amino-6paramethoxy-phenyl-pyridaziniumbromide), and ( \pm )-sulpiride were gifts respectively from Novartis (Basel, Switzerland), Sanofi (Paris, France), and Synthelabo (Paris, France). All drugs were dissolved in water except CNQX, prazosin, and sulpiride, which were dissolved in DMSO. Final concentrations of DMSO in the superfusion medium were always lower than $0.1 \%$. This concentration had no effect by itself. All final solutions were prepared just before their use.

\section{Visualization of biocytin}

In some slices, cells were recorded with biocytin-containing microelectrodes to allow their subsequent identification. At the end of the recording session, these slices were fixed overnight in a $4 \%$ paraformaldehyde solution at $4^{\circ} \mathrm{C}$. They were then cryoprotected for $2-4 \mathrm{hr}$ in a $20 \%$ 
sucrose solution and stored in antifreeze at $-20^{\circ} \mathrm{C}$ until processed. Sections were washed three times (15 min each) in PBS and incubated for $30 \mathrm{~min}$ in $10 \%$ normal goat serum in PBST 0.1\% (Dako, Copenhagen, Denmark) (0.1 M PBS buffer containing $0.1 \%$ Triton X-100). The biocytin was revealed by a $3 \mathrm{hr}$ incubation at room temperature in streptavidin-FITC diluted 1:500 in PBST 1\% (0.1 M PBS buffer containing 1\% Triton X-100). After three final washes in PBST 0.1\%, sections were mounted on microscope slides and coverslipped with a Slow Fade Antifade Kit (Molecular Probes, Eugene, OR). Digitized confocal images were acquired at $1024 \times 1024$ pixel resolution with a $63 \times$ water immersion objective (NA 1.2) using a Leica model TCS-SP2 laser scanning microscope (Leica Microsystems).

\section{Data analysis and statistics}

In the extracellular experiments, changes in firing rate were quantified by the difference between the mean firing frequency over the 5 min preceding the application of a given compound (control period) and over the minute during which the drug produced its maximal effect expressed as percentage of the basal frequency. Only neurons with a firing rate per minute that varied by $<5 \%$ during the control period were used for experiments. Drugs were considered to have a significant effect on the firing rate if (1) a difference of $25 \%$ from the mean basal frequency of discharge was observed and (2) at least $50 \%$ recovery took place during the washout period. A neuron was considered inhibited or excited by DA or NE if it reacted according to the criteria defined above for at least one of the concentrations that was tested.

For the study of the relationships between baseline characteristics (spike duration and firing rate) of neurons and their response to DA/NE, spike durations were evaluated by the calculation of the mean duration in a randomly chosen series of 10 successive spikes, whereas firing rate was evaluated by the calculation of the mean firing rate over the $5 \mathrm{~min}$ control period preceding the first DA/NE application in the presence of synaptic blockers.

All data were analyzed and plotted using Sigma Plot 3.03 (SPSS, Chicago, IL), Sigma Stat 2.03 (SPSS), or Statview 5.01 (Abacus Concepts, Berkeley, CA). All results in the text are expressed as means \pm SEM. Most data were compared with two-tailed Student's $t$ test or one-way ANOVA followed when appropriate by the post hoc Fisher protected least significant difference (PLSD) test. The Mann-Whitney nonparametrical test was substituted, however, in a few cases in which the homoscedasticity condition was not met by the data. The KolmogorovSmirnov one-tailed test for two samples was additionally used to compare the duration of spikes and mean firing frequencies of cells. Differences are considered significant for $p \leq 0.05$.

\section{RESULTS}

\section{Effects of DA on the membrane potential of POM neurons}

Long-lasting $(>1 \mathrm{hr})$ stable intracellular recordings could be obtained from 17 cells located in the POM. Most of the cells were located in the caudal part of the POM just ventral to the anterior commissure. The impaled neurons were spontaneously active. When prevented from firing (by exposure to $0.5-1 \mu \mathrm{M}$ TTX), their mean resting potential was $-50.2 \pm 1.6 \mathrm{mV}(n=17)$. The mean membrane input resistance and time constant assessed using $100 \mathrm{msec}$ hyperpolarizing $(-100 \mathrm{pA})$ current pulses were $236 \pm 23 \mathrm{M} \Omega(n=17)$ and $18.4 \pm 1.6 \mathrm{msec}(n=17)$, respectively. The mean action potential threshold was $-42 \pm 2 \mathrm{mV}(n=16)$. The action potentials displayed a mean amplitude of $33 \pm 1 \mathrm{mV}$ $(n=16)$. This value is probably underestimated because of the high resistance of the microelectrodes that were used. Action potentials of similar amplitude have been described recently in the avian basal ganglia (Ding and Perkel, 2002).

The stability of the recordings and the high input resistance of the neurons suggested that they were in good condition. This was further supported by the visualization of the biocytin-filled neurons, which possessed long and thin neurites without any evidence of morphological alterations (Fig. 1).

The effects of DA on the membrane potential of POM neurons
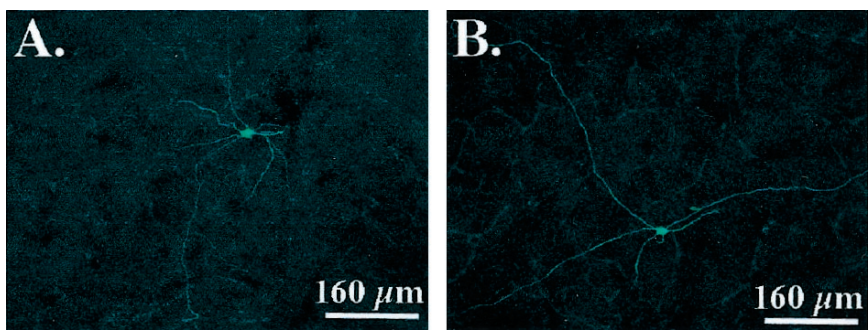

Figure 1. Confocal photomicrographs illustrating two POM neurons filled with biocytin during intracellular recording. These cells were hyperpolarized by both DA and NE.

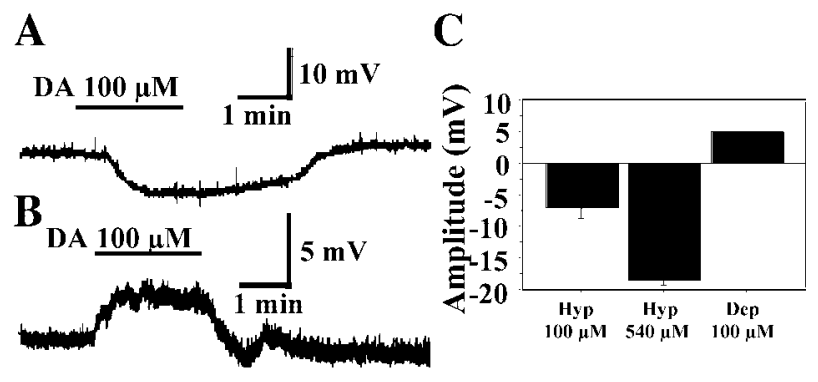

Figure 2. Intracellular recordings of one DA-induced hyperpolarization and one depolarization in POM neurons. $A$, Current-clamp recording of a typical POM neuron showing a membrane hyperpolarization induced by DA $(100 \mu \mathrm{M})$. The membrane potential was set initially at $-70 \mathrm{mV}$ by the injection of $-90 \mathrm{pA}$. $B$, Current-clamp recording of another POM neuron showing a depolarization induced by DA $(100 \mu \mathrm{M})$. The membrane potential was set at $-70 \mathrm{mV}$ by the injection of $-200 \mathrm{pA}$. $C$, Mean amplitude $( \pm$ SEM) of the effects of DA at two different concentrations $(100$ and $540 \mu \mathrm{M})$ on the membrane potential of two groups of POM neurons. The number of experiments is 10,3 , and 1 from left to right. Note that three neurons that did not respond to DA are not illustrated in this figure. Note that scales in $A$ and $B$ are different. All recordings were performed in the presence of $0.5-1 \mu \mathrm{M}$ TTX. DA was superfused during the period indicated by the bars. Hyp, Hyperpolarization; Dep, depolarization.

were examined in the current-clamp mode. For these experiments, cells were hyperpolarized to $-70 \mathrm{mV}$ by injection of a DC current. As already mentioned, POM neurons exhibited robust synaptic potentials that were caused by the activation of glutamatergic and GABAergic receptors (Cornil et al., 2001). To ensure that the recorded effects were mediated by a direct action on the cell that was recorded, all subsequent experiments were performed in the presence of TTX $(0.5-1 \mu \mathrm{M})$. Superfusion of DA $(100 \mu \mathrm{M})$ induced a membrane hyperpolarization of $6 \pm 0.5 \mathrm{mV}$ in the majority of the cells ( $n=10$ of 14 neurons) (Fig. $2 A$ ). In one cell, bath application of DA $(100 \mu \mathrm{M})$ induced a biphasic response, which consisted of a membrane depolarization of $6 \mathrm{mV}$ followed by a small hyperpolarization of $3 \mathrm{mV}$ (Fig. $2 B$ ). In three other cells, dopamine had no effect on the membrane potential. The DA-induced hyperpolarizations and depolarizations were fully reversible and showed no obvious desensitization after multiple applications of the same concentration of DA ( $n=7$ cells). The membrane hyperpolarization was apparently concentration dependent (Fig. 2C), as suggested by the fact that a much larger effect was detected when the concentration of DA was raised from 100 to $540 \mu \mathrm{M}$.

To investigate the type of receptor mediating the DA-induced hyperpolarization in POM neurons, the effects of selective dopaminergic antagonists were examined. As illustrated in Figure 3, neither sulpiride ( $1 \mu \mathrm{M} ; n=5)$, a D2-like receptor antagonist, nor 
A Control

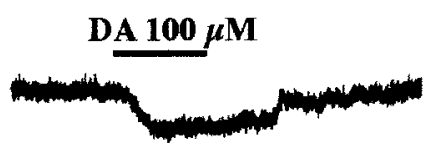

B Sulpiride $1 \mu \mathrm{M}$
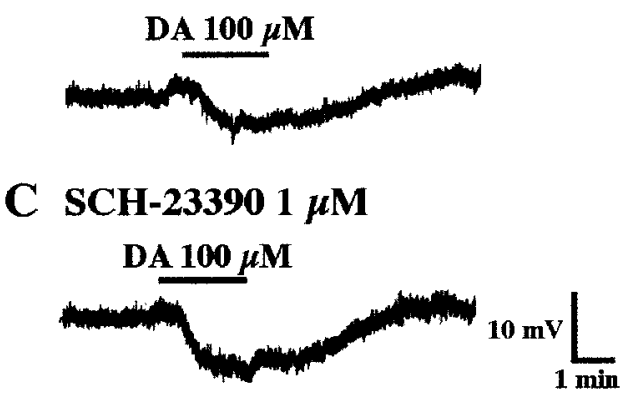

Figure 3. The DA-induced hyperpolarization in POM neurons is not blocked by antagonists of dopaminergic receptors. $A$, DA-induced hyperpolarization under control conditions in a POM neuron. In the same neuron, the DA-induced hyperpolarization was antagonized neither by 1 $\mu \mathrm{M}$ sulpiride, a D2-like receptor antagonist $(B)$, nor by $1 \mu \mathrm{M} \mathrm{SCH}-23390$, a D1-like receptor antagonist $(C)$. Each antagonist was superfused for 10 min before the application of DA. The membrane potential was set at -70 $\mathrm{mV}$ by the injection of $\sim 100 \mathrm{pA}$. All recordings were performed in the presence of $0.5-1 \mu \mathrm{M}$ TTX. DA was superfused during the period indicated by the bars.

SCH-23390 (1 $\mu \mathrm{M} ; n=4)$, a D1-like receptor antagonist, was able to block the hyperpolarization induced by DA $(100 \mu \mathrm{M})$, despite the fact that these antagonists were used at concentrations at least 100-1000 times higher than their $K_{\mathrm{i}}$ for their respective receptor (Sugamori et al., 1994; Demchyshyn et al., 1995; Missale et al., 1998). Taken together, these results suggest that the DA-induced hyperpolarization was not mediated by dopaminergic receptors. We therefore decided to analyze the pharmacology of this response in more detail using extracellular recordings.

\section{Dopaminergic control of the firing rate of POM neurons}

Extracellular recordings were obtained from 110 neurons located within the POM. These neurons had a spontaneous firing rate ranging between 0.2 and $15.1 \mathrm{~Hz}(5.13 \pm 0.31 \mathrm{~Hz} ; n=102)$. Their action potential duration was in the range of 1.1-3.0 msec (1.94 \pm 0.04 msec; $n=110)$. Most of the cells $(95 \%)$ showed a pacemaker or slightly irregular (single spikes) pattern of discharge, whereas the others $(5 \%)$ exhibited a more bursting pattern. There was no correlation between this firing pattern and the effects of DA observed in the experiments. Superfusion of the synaptic blockers regularized the firing pattern and slightly increased the average firing rate (from $5.13 \pm 0.31$ to $5.54 \pm 0.34 ; t=3.329$; df $=$ 86; $2 p<0.001)$.

As expected on the basis of intracellular recordings, superfusion of DA had profound effects on the firing rate of POM neurons (Fig. 4). The firing rate of most neurons (52\%; $n=55$ of $105)$ was decreased by DA applied at $10(n=6), 30(n=35), 50$ $(n=11)$, or $100 \mu \mathrm{M}(n=3)$. In contrast, the firing of $24 \%$ of these neurons (25 of 105) was increased by DA at $10(n=2), 30(n=$ 16), $50(n=4), 100(n=2)$, and $150 \mu \mathrm{M}(n=1)$.

In the remaining $24 \%$ of cells $(n=25$ of 105$)$, DA had no detectable effect or effects of too small a magnitude to be considered reliable (see Materials and Methods), even at the highest
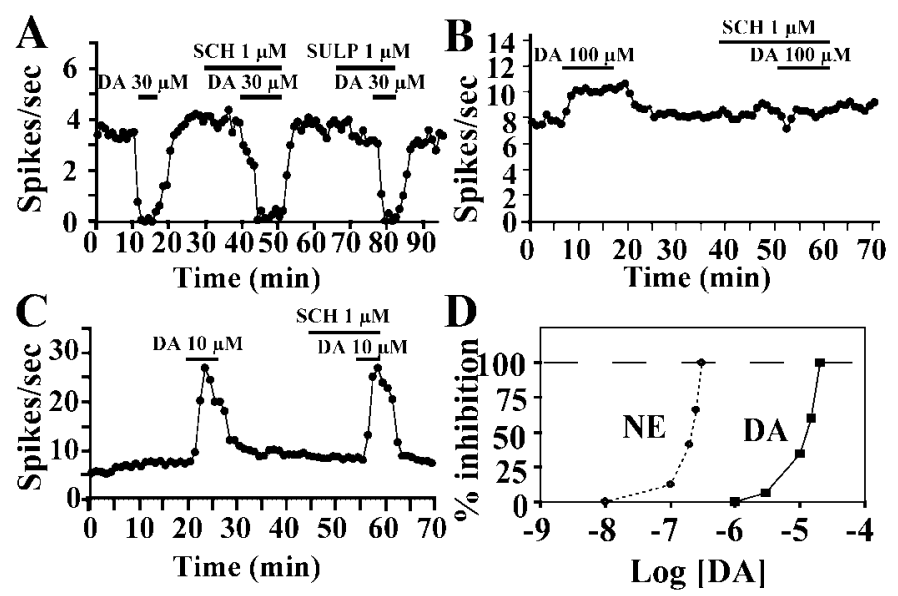

Figure 4. Extracellular recordings illustrating the effects of dopaminergic antagonists on DA-induced inhibitions and excitations in POM neurons. $A$, Example of a complete inhibition of firing induced by DA (30 $\mu \mathrm{M})$ under control conditions. This effect was not blocked by the superfusion of $1 \mu \mathrm{M} \mathrm{SCH}-23390(S C H)$ and $1 \mu \mathrm{M}$ sulpiride (SULP). B, Example of an excitation induced by DA under control conditions. This effect was blocked by $1 \mu \mathrm{M}$ SCH-23390 (SCH). C, Example of an excitation induced by DA. This effect was not blocked by $1 \mu \mathrm{M}$ SCH-23390. D, Example of a concentration-response curve for a DA- and NE-induced inhibition in a POM neuron (to calculate $\mathrm{EC}_{50}$, one additional point was added to the raw data for the maximal effect; see Materials and Methods). All experiments were performed in the presence of CGP-35348 $(30 \mu \mathrm{M})$, SR-95531 $(10 \mu \mathrm{M}), \mathrm{CNQX}(10 \mu \mathrm{M})$, and MK-801 $(10 \mu \mathrm{M})$. Drugs were superfused during the period indicated by the bars.

concentration of DA. When present, changes in firing rate generally appeared at the end of the first minute of superfusion of the solution containing DA, which corresponds approximately to the time needed for the modified ACSF to reach the slice. The DA-induced inhibitions were fully reversible and concentration dependent. The $\mathrm{EC}_{50}$ value for the inhibitory effect of DA was $78 \pm 40 \mu \mathrm{M}(n=11)$ (Fig. $4 D)$. As already mentioned (see Materials and Methods), no concentration-response curve for the DA-induced excitation could be calculated.

\section{Relationship between basal firing rates and the nature of dopamine effects}

We wondered whether a correlation exists between the nature of the response to DA (inhibition vs excitation vs no response, as defined above) and the baseline firing rate or spike duration of neurons. A one-way ANOVA indicated the existence of highly significant differences in the firing rate of these three classes of neurons $\left(F_{(2,87)}=5.114 ; p=0.0079\right)$, with the neurons inhibited by DA firing less rapidly $(4.49 \pm 0.39 \mathrm{~Hz} ; n=44)$ than those excited by DA $(5.97 \pm 0.70 \mathrm{~Hz} ; n=23)$, which themselves had a slower rate than nonresponding neurons $(6.87 \pm 0.72 \mathrm{~Hz} ; n=23)$. Post hoc Fisher PLSD tests indicated that inhibited neurons had a significantly slower firing rate than the two other types $(p<$ 0.05). A similar analysis of the basal spike duration, however, failed to identify significant differences between these three groups of neurons $\left(F_{(2,100)}=1.789 ; p=0.1724\right)$.

The proportions of neurons exhibiting different firing rates (intervals of $0.5 \mathrm{~Hz}$ ) or spike durations (intervals of $0.1 \mathrm{msec}$ ) were also computed separately for inhibited, excited, or nonreactive neurons.

The comparison of the cumulative frequencies of the firing rates in the three types of neurons by the Kolmogorov-Smirnov two-samples test confirmed that a large proportion of DA- 


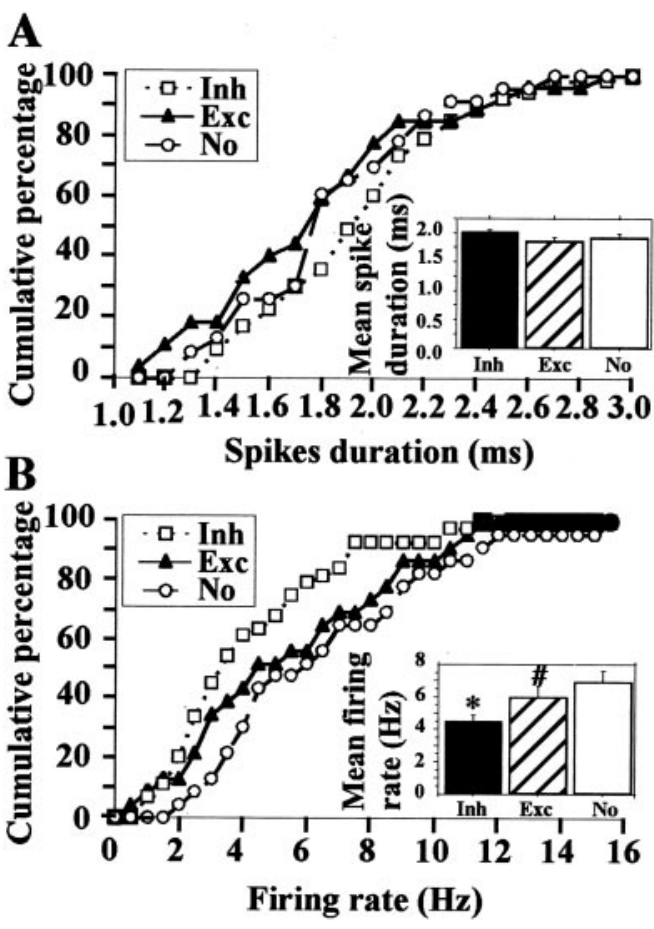

Figure 5. Relationship between the spike duration and frequency of POM neurons and the nature of the effect produced by DA. A, Cumulative percentage of the spike durations in relation to the nature of response to DA. $B$, Cumulative percentage of firing rates in relation to the nature of response to DA. In both panels the insets show the average values of each measure for the three classes of neurons according to their response to DA. ${ }^{*} p \leq 0.05$, inhibition $(\operatorname{Inh})$ versus excitation $($ Exc $) ;{ }^{*} p \leq 0.05$, excitation $(E x c)$ versus no response $(\mathrm{No})$.

inhibited cells display a lower firing rate than nonresponding cells (Fig. 5A) $\left(\chi^{2}=6,50 ; \mathrm{df}=2 ; p<0.05\right)$. By contrast, no statistically significant difference could be detected in the distribution of spike durations among the three types of cells classified according to their response to DA (Fig. $5 B$ ).

\section{Effects of dopamine antagonists}

To investigate further the pharmacology of these responses, brain slices were preincubated for at least $10 \mathrm{~min}$ with selective dopaminergic antagonists before DA was added to the medium. As in intracellular experiments, the D2 antagonist sulpiride $(1 \mu \mathrm{M})$ failed to suppress in 13 cells the DA-induced inhibitory effects, regardless of the concentration of DA that had been used $(30 \mu \mathrm{M}$, $n=4 ; 50 \mu \mathrm{M}, n=5 ; 100 \mu \mathrm{M}, n=2 ; 150 \mu \mathrm{M}, n=1 ; 300 \mu \mathrm{M}, n=$ 1) (see Fig. $4 A$ for an example at $30 \mu \mathrm{M} \mathrm{DA}$ ). A partial suppression of the DA effect was observed in three other cells (DA used at $10 \mu \mathrm{M}, n=1 ; 30 \mu \mathrm{M}, n=2$; data not shown).

The D1 antagonist SCH-23390 (1 $\mu \mathrm{M})$ similarly did not block firing inhibitions induced by DA in the four cells in which it was tested (30 $\mu \mathrm{M}, n=2 ; 50 \mu \mathrm{M}, n=1 ; 100 \mu \mathrm{M}, n=1$ ) (Fig. 4A). These results were consistent with those obtained by intracellular recording and further suggested that DA-induced inhibitions of firing were not mediated by dopaminergic receptors.

Contrasting results were obtained in the analysis of the excitatory effects of DA ( $10 \mu \mathrm{M}, n=3 ; 30 \mu \mathrm{M}, n=16 ; 50 \mu \mathrm{M}, n=5 ; 100$ $\mu \mathrm{M}, n=1 ; 150 \mu \mathrm{M}, n=1)$. These excitations were blocked by $\mathrm{SCH}-23390(1 \mu \mathrm{M})$ in six of eight cells $(30 \mu \mathrm{M}, n=4 ; 50 \mu \mathrm{M}, n=$ $1 ; 100 \mu \mathrm{M}, n=1$ ) (Fig. $4 B$ ) but were unaffected in two other cells (10 $\mu \mathrm{M}, n=1 ; 30 \mu \mathrm{M}, n=1)$ (Fig. 4C). These results thus suggested that the excitatory effects of DA could be attributed to its interaction with dopaminergic receptors in a higher proportion of cells than its inhibitory effect. They also indicated that the concentration of SCH-23390 used in these experiments was sufficient to block an effect of DA in our test conditions.

\section{Effects of dopamine agonists}

Data presented so far have indicated that few neurons in the quail POA are affected by specific dopaminergic antagonists, despite the fact that they respond to DA. To further investigate the origins of this paradoxical finding, the effects of selective dopaminergic agonists were also investigated. Consistent with the results obtained with antagonists, bath application of the D2-like receptor agonist quinpirole at a concentration of $1 \mu \mathrm{M}$, which is supramaximal for extracellular recordings (Bowery et al., 1994) and effective in intracellular recordings (Lacey et al., 1987), produced no effect in a majority of cells $(n=19$ of 25). In the remaining neurons ( 6 of 25), a variable degree of inhibition of the firing rate was detected ranging from a few percent decrease to a complete suppression of electrical activity. These results confirm that only a small proportion of POM neurons possess functional dopaminergic D2-like receptors in the quail POA.

Despite the fact that the D1 antagonist SCH-23390 blocked the excitatory effect of DA in a substantial proportion of neurons (see above), the D1 agonist SKF-38393 at a $1 \mu \mathrm{M}$ concentration [shown to be maximally effective in increasing efflux of cAMP from blocks of rat striatum (Stoof and Kebabian, 1981)] had no effect in the majority of the cells that were tested ( $n=13$ of 14) and increased the electrical activity in only one neuron. It is known, however, that SKF-38393 is only a partial DA agonist in terms of in vitro adenylate cyclase stimulation, with an intrinsic activity of only $45-70 \%$ compared with DA. Other effects of D1 receptor activation mediated by an alternative second messenger system may also not be (fully) stimulated by SKF-38393 [see Ruskin et al. (1998) for additional discussion and references].

\section{Effects of norepinephrine}

$\mathrm{NE}$ also affected the firing rate of POM neurons (Fig. 6). The firing rate of most neurons $(62 \% ; n=35$ of 56) was decreased by $\mathrm{NE}$ applied at $1(n=1), 10(n=16), 30(n=17)$, or $100 \mu \mathrm{M}(n=$ 1). In a smaller population of neurons ( 6 of 56; i.e., $11 \%)$, NE (30 $\mu \mathrm{M}, n=4 ; 100 \mu \mathrm{M}, n=2)$ increased the firing rate. In the remaining $27 \%$ of cells (15 of 56), NE had no detectable effect or effects of too small a magnitude to be considered reliable (see Materials and Methods). When both amines were applied successively, NE mimicked the effect of DA in 83\% (24 of 29) (Fig. $6 A, B)$ of the cells, whereas $\mathrm{NE}$ and DA produced different effects in a few neurons $(17 \% ; n=5$ of 29) (Fig. $6 C$ ). Most of the cells exhibiting opposite responses for DA and $\mathrm{NE}$ were excited by DA and inhibited by NE (four of five).

Concentration-dependent effects were observed when the same cells were tested with increasing $\mathrm{NE}$ concentrations. The $\mathrm{EC}_{50}$ value for the NE-induced inhibition was $9.3 \pm 5.2 \mu \mathrm{M}(n=7)$ (Fig. $4 D$ ). This value was significantly smaller than the $\mathrm{EC}_{50}$ of DA (Mann-Whitney test; $\mathrm{U}=12 ; \mathrm{n} 1=11$ and $\mathrm{n} 2=7 ; 2 p=$ 0.0164). The effects of NE were also fully reversible.

Contrary to what had been observed for DA, no statistically significant difference could be detected in either the firing rate or the spike duration among the three types of cells classified according to their response (inhibition, excitation, no response) to $\mathrm{NE}\left(F_{(2,51)}=0.023, p=0.9775\right.$ and $F_{(2,52)}=0.336, p=0.7161$, respectively). In addition, the proportions of cells in these three 


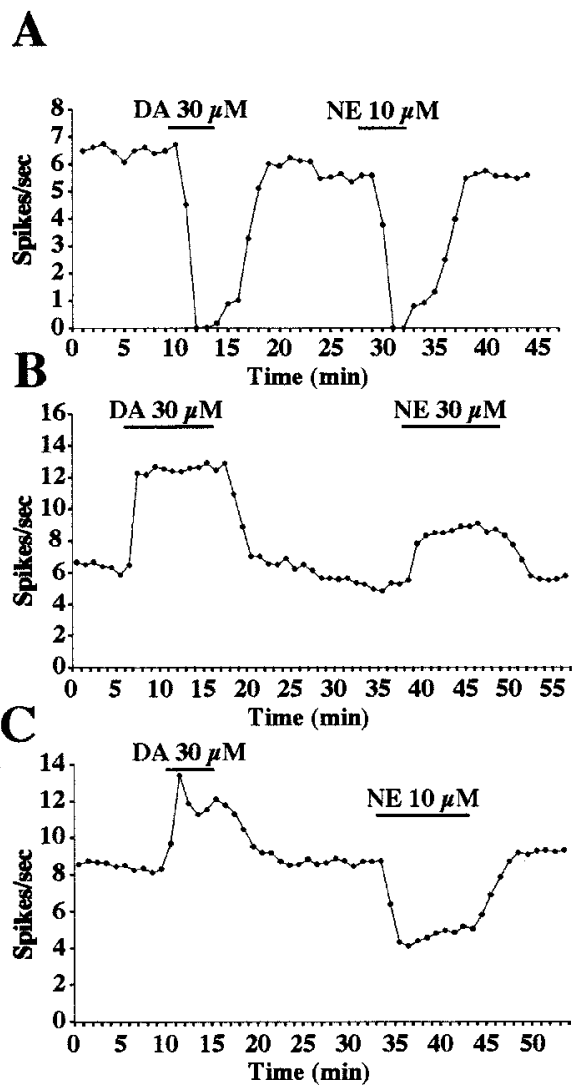

Figure 6. NE mimics the inhibitory and excitatory effects of DA in most extracellularly recorded cells. $A$, Bath application of $30 \mu \mathrm{M}$ DA and $10 \mu \mathrm{M}$ $\mathrm{NE}$ completely inhibits the firing in a POM neuron. $B$, Bath application of $30 \mu \mathrm{M}$ DA and $30 \mu \mathrm{M} \mathrm{NE}$ increases the firing rate of a POM neuron. $C$, DA and NE bath applications produce opposite effects in a POM neuron. All experiments were performed in the presence of CGP-35348 $(30 \mu \mathrm{M})$, SR-95531 $(10 \mu \mathrm{M})$, CNQX $(10 \mu \mathrm{M})$, and MK-801 $(10 \mu \mathrm{M})$. Drugs were superfused during the period indicated by the bars.

subgroups exhibiting different firing rates (intervals of $0.5 \mathrm{~Hz}$ ) or spike durations (intervals of $0.1 \mathrm{msec}$ ) were not different when compared by the Kolmogorov-Smirnov two-sample test (data not shown). These results should be interpreted with caution, however, because a smaller number of cells was available for this analysis than in the case of DA.

\section{Effects of noradrenergic antagonists}

To test the hypothesis that DA produces its inhibitory effects mainly by interaction with $\alpha_{2}$ receptors, we examined the effect of the $\alpha_{2}$-adrenergic antagonist yohimbine on the response to DA. As shown in Figure $7 A, 1 \mu \mathrm{M}$ yohimbine [ $>100$ times its $K_{\mathrm{i}}$ for the $\alpha_{2}$-noradrenergic receptor (Hieble and Ruffolo, 1996)] suppressed the inhibitory effect of DA in 12 of 15 cells. In the three remaining DA-inhibited cells that were not affected by yohimbine, sulpiride $(1 \mu \mathrm{M})$ also had no effect, suggesting that DA might interact with yet another receptor.

Sulpiride $(1 \mu \mathrm{M})$ had no effect in six of seven neurons exhibiting DA-induced inhibitions blocked by yohimbine. In the last cell displaying this phenotype, sulpiride partially blocked the DAinduced inhibitions, suggesting the presence of multiple receptors on these cells (see also below).

The application of $1 \mu \mathrm{M}$ prazosin $\left(\alpha_{1}\right.$-noradrenergic antagonist) blocked the excitation produced by DA in all cells that were tested ( $n=6$ of 6 ). This result was surprising in view of the fact
A
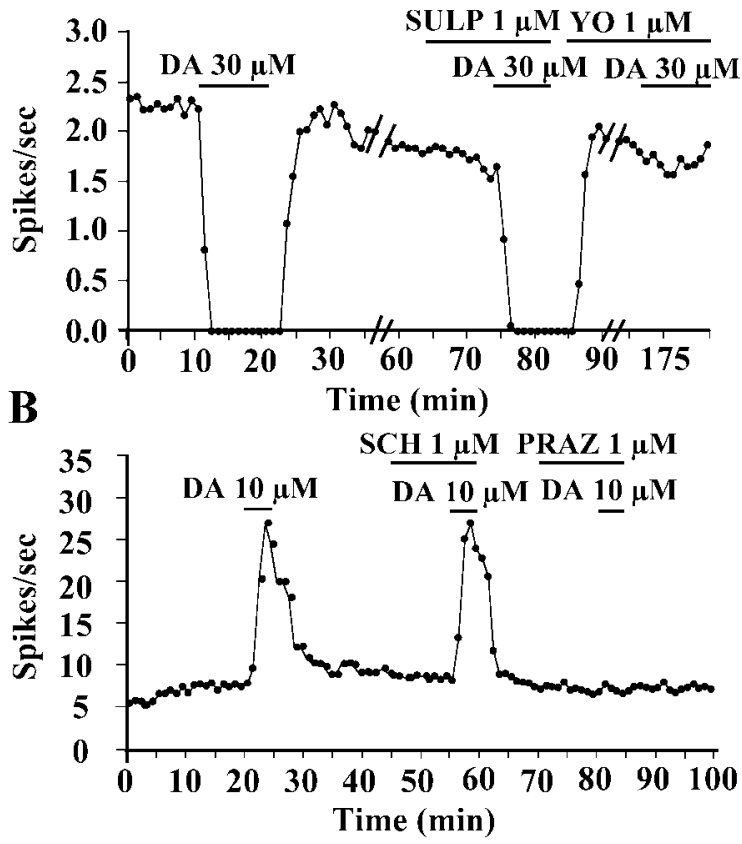

Figure 7. The inhibitory effects of DA are not blocked by a D2 receptor antagonist but are suppressed by specific $\alpha$-noradrenergic antagonists. $A$, The complete inhibition of the firing of a POM neuron induced by DA ( 30 $\mu \mathrm{M})$ is not blocked by $1 \mu \mathrm{M}$ sulpiride $(S U L P)$ but is blocked by $1 \mu \mathrm{M}$ yohimbine $(Y O)$, an $\alpha_{2}$-noradrenergic antagonist. $B$, Example of a DAinduced excitation of the firing rate in a POM neuron that is not blocked by $1 \mu \mathrm{M}$ SCH-23390 $(S C H)$ but is suppressed by $1 \mu \mathrm{M}$ prazosin $(P R A Z)$, an $\alpha_{1}$-adrenoreceptor antagonist. All experiments were performed in the presence of CGP-35348 (30 $\mu \mathrm{M})$, SR-95531 (10 $\mu \mathrm{M})$, CNQX (10 $\mu \mathrm{M})$, and MK-801 $(10 \mu \mathrm{M})$. Drugs were superfused during the period indicated by the bars.

that the excitation of DA was blocked in a majority $(n=6$ of 8$)$ of cells by the D1 antagonist SCH-23390 (see above). This apparent contradiction presumably results from random variations in the types of receptors (dopaminergic or noradrenergic) expressed in the cells that were investigated. One can assume that cells expressing D1 or $\alpha_{1}$ receptors coexist in the quail POA and that the former were serendipitously investigated in the majority of experiments with SCH-23390, whereas the latter were studied with prazosin. This interpretation is supported by the example shown in Figure $7 B$. In one of the two cells excited by DA in an SCH-23390 resistant manner (and thus presumably not expressing D1 receptors), we observed a complete suppression of DA effects after a preincubation with prazosin. It is therefore likely that, in general, separate populations of neurons express the D1 and $\alpha_{1}$ receptors.

\section{$\mathrm{pK}_{\mathrm{B}}$ of yohimbine}

If DA binds to the same receptor as NE to produce its inhibitory effect, the potency of yohimbine for displacing the DA and NE concentration-response curves should be the same. This potency can be assessed by determining the corresponding values of $\mathrm{pK}_{\mathrm{B}}$. The $\mathrm{pK}_{\mathrm{B}}$ is a measure of the displacement by an antagonist of the binding of an agonist to its receptor, independent of the affinity (or $\mathrm{EC}_{50}$ ) of the agonist for this receptor. Therefore if two different agonists (in the present case DA and NE) are similarly displaced from their receptor by a same antagonist (in the present case the $\alpha_{2}$-noradrenergic antagonist yohimbine), it can be concluded that they bind to the same receptor (Kenakin, 1984; 


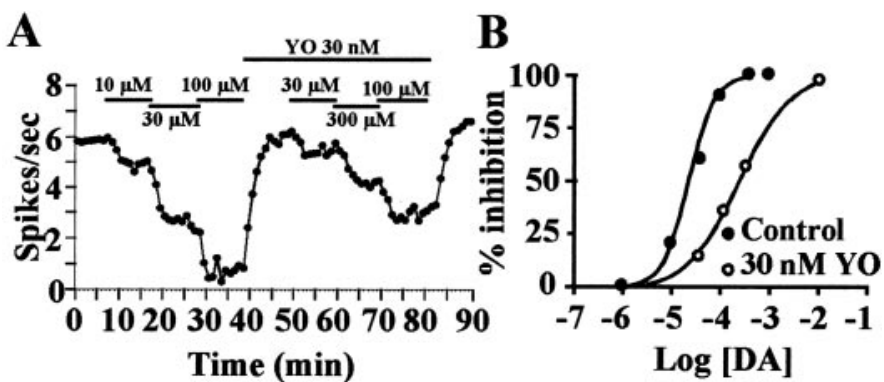

Figure 8. Displacement of the concentration-response curve of the inhibitory effect of DA by yohimbine. $A$, Experiment illustrating the effect of a low concentration of yohimbine $(Y O)$ on the DA concentrationresponse curve. All concentrations refer to DA except where indicated. $B$, Graphical representation of the concentration-response curve of DA in control conditions $(\bullet)$ and in the presence of the $\alpha_{2}$-antagonist ( $($ ). All experiments were performed in the presence of CGP-35348 $(30 \mu \mathrm{M})$, SR-95531 $(10 \mu \mathrm{M})$, CNQX $(10 \mu \mathrm{M})$, and MK-801 (10 $\mu \mathrm{M})$. Drugs were superfused during the period indicated by the bars.

Jenkinson et al., 1995). A typical experiment is illustrated in Figure $8 A$. As shown in Figure $8 B$, this concentration of yohimbine markedly increased the $\mathrm{EC}_{50}$ of $\mathrm{DA}$. The calculated $\mathrm{pK}_{\mathrm{B}}$ value for yohimbine was $8.36 \pm 0.05(n=5$ cells $)$. Similar experiments performed with $\mathrm{NE}$ yielded very similar values (8.01 $\pm 0.19 ; n=4$ cells). There was no significant difference between the $\mathrm{pK}_{\mathrm{B}}$ values of yohimbine for the two agonists $(t=$ 1.961 ; $\mathrm{df}=7 ; 2 p=0.091$ ); the slightly higher $\mathrm{pK}_{\mathrm{B}}$ obtained for DA indicated, if anything, a more potent antagonism of the effect of DA. These values are also very close to the $\mathrm{pK}_{\mathrm{B}}$ of yohimbine for $\alpha_{2}$ receptors in rat (Hieble and Ruffolo, 1996). Furthermore, nearly identical values were obtained for the two $\mathrm{pK}_{\mathrm{B}} \mathrm{s}$ in the single neuron for which both measurements could be made $\left(\mathrm{pK}_{\mathrm{B}}\right.$ for $\mathrm{DA}=8.32 ; \mathrm{pK}_{\mathrm{B}}$ for $\mathrm{NE}=8.57$ ). Taken together, these experiments demonstrate that the inhibitory effect of DA on the firing rate of most POM neurons results from the activation of $\alpha_{2}$-noradrenergic receptors.

\section{Effects of DA do not result from its transformation by dopamine- $\beta$-hydroxylase}

Activation of $\alpha_{2}$ receptors during the superfusion of DA could be attributable to either an activation of these receptors by DA itself or a transformation of DA into NE within the slice and subsequent binding of NE to its receptors. This originally appeared quite unlikely because, when present, changes in firing rate generally appeared at the end of the first minute of superfusion with the DA-containing solution, which corresponds approximately to the time needed for the modified ACSF to reach the slice. Therefore, it was hardly conceivable that sufficient amounts of NE could be produced by metabolism of DA in such a short time. This idea was experimentally evaluated, however, by testing the effects of DBH inhibitors.

Superfusion for at least $10 \mathrm{~min}$ of either cysteine $(1 \mathrm{mM} ; n=4$ of 4) (Fig. 9A) or fusaric acid (100 $\mu \mathrm{m} ; n=4$ of 4) (Fig. 9B), two known inhibitors of $\mathrm{DBH}$, failed to significantly modify the inhibitory effect of DA. Taken together, these data suggest that the effects of DA on the $\alpha_{2}$-noradrenergic receptors are not mediated by a metabolic conversion of DA into NE.

The same conclusion was reached concerning the excitatory effect of DA, which could not be blocked by preincubations with $100 \mu \mathrm{M}$ fusaric acid $(n=4)$ (Fig. $9 C)$ or $1 \mathrm{~mm}$ cysteine $(n=3$; data not shown).
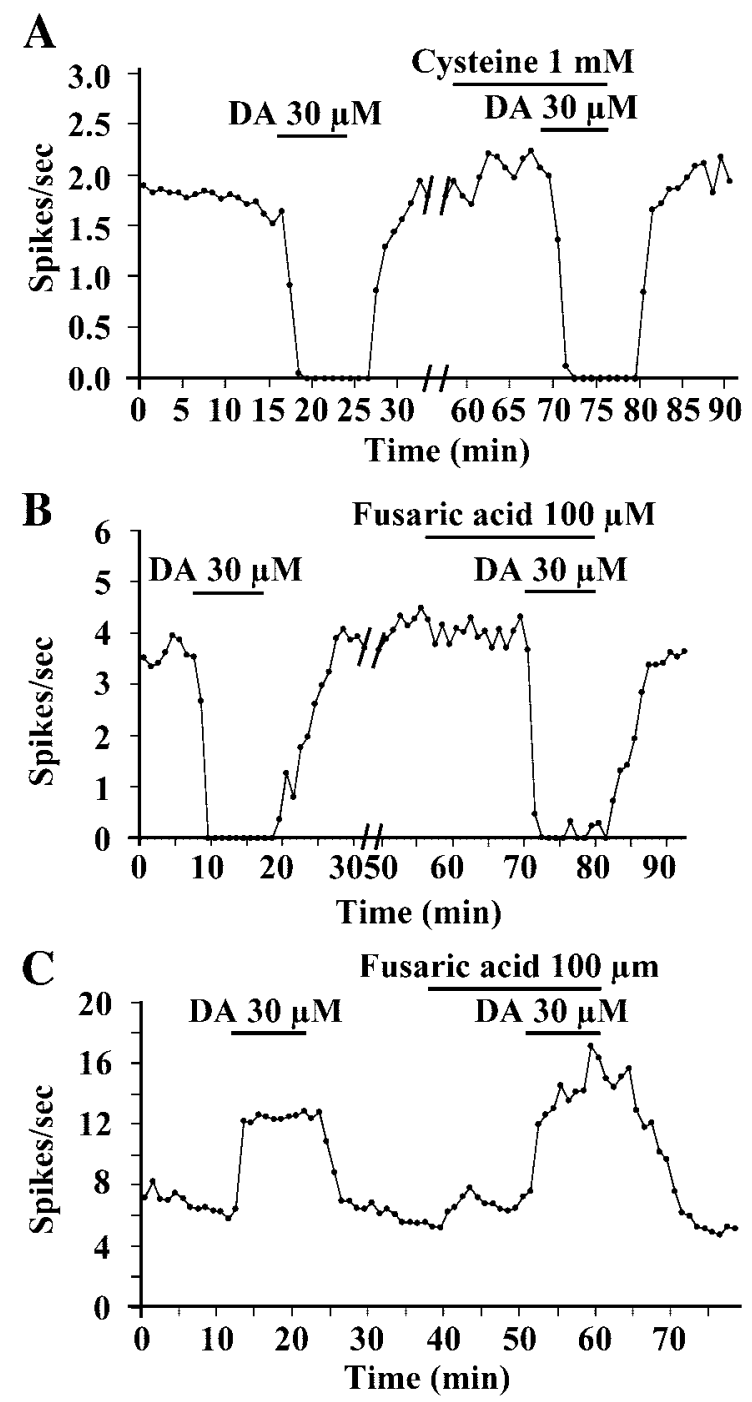

Figure 9. Inhibitors of dopamine- $\beta$-hydroxylase, the enzyme catalyzing the conversion of DA into NE, do not block the effects of DA. The complete inhibition of the firing of a POM neuron induced by DA $(30 \mu \mathrm{M})$ is not blocked by the bath application of $1 \mathrm{~mm}$ cysteine $(A)$ or by $100 \mu \mathrm{M}$ fusaric acid $(B)$. $C$, The excitation of a POM neuron produced by DA (30 $\mu \mathrm{M})$ is not blocked by the bath application of $100 \mu \mathrm{M}$ fusaric acid. All experiments were performed in the presence of CGP-35348 (30 $\mu \mathrm{M})$, SR-95531 $(10 \mu \mathrm{M})$, CNQX $(10 \mu \mathrm{M})$, and MK-801 $(10 \mu \mathrm{M})$. Drugs were superfused during the period indicated by the bars.

The concentration of fusaric acid used here rapidly decreases NE concentration in rat spleen strips (Bencsics et al., 1997) and blocks DBH activity in quail brain homogenates, as reflected by the feedback effect of the accumulating DA on TH activity (Baillien et al., 1999). Intraperitoneal injection of fusaric acid also decreases the brain NE levels (Nagatsu et al., 1970; Bungo et al., 2001). Similarly, the concentration of cysteine used here inhibits DBH activity in vitro (Nagatsu et al., 1967; Terry and Craig, 1985), and cysteine uptake in cultured neurons occurs within 5 min (Shanker et al., 2001). Therefore there is every reason to believe that these compounds efficiently blocked DBH activity in the slices under study.

\section{Complex actions of dopamine in a subset of POM neurons}

Together, the experiments described above clearly indicate that neurons in the quail POA express the two types of dopaminergic 
A
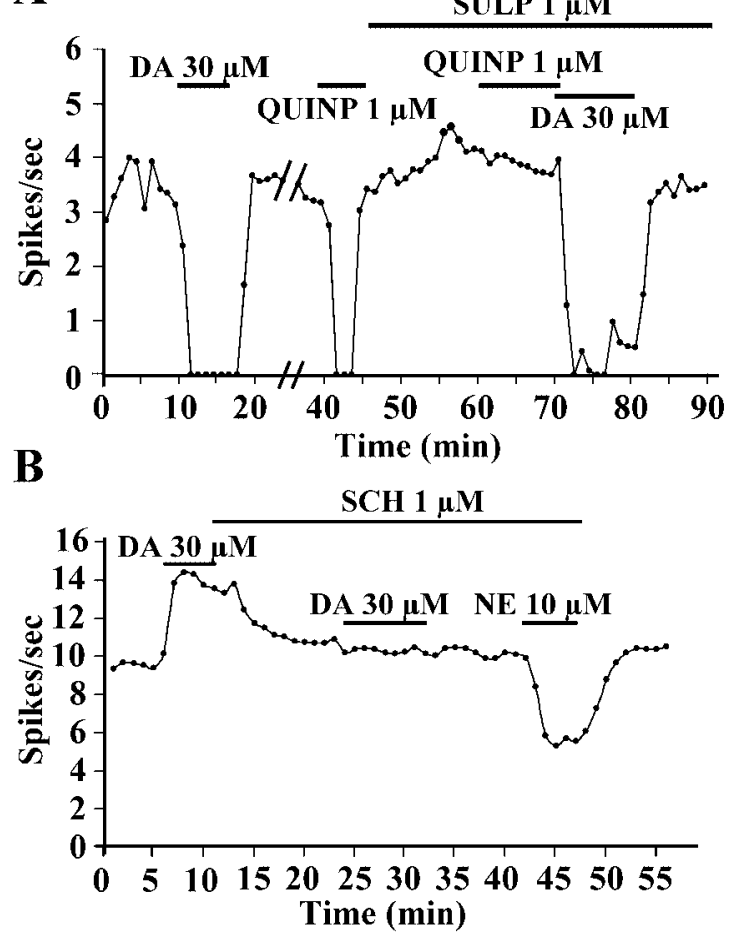

Figure 10. Complex actions of DA in a subset of POM neurons. $A$, The complete inhibition of the firing rate induced in a POM neuron by $1 \mu \mathrm{M}$ quinpirole $(Q U I N P)$ is blocked by $1 \mu \mathrm{M}$ sulpiride (SULP). However, sulpiride does not block the DA-induced inhibition, suggesting the involvement of $\alpha_{2}$-noradrenergic receptors. $B$, Example of POM neuron showing a DA-induced excitation and a NE-induced inhibition. The blockade of the DA-induced excitation by $1 \mu \mathrm{M} \mathrm{SCH}-23390(\mathrm{SCH})$ suggests that the excitation is mediated by $\mathrm{D} 1$ receptors, whereas the NEinduced inhibition is probably mediated by $\alpha_{2}$ noradrenergic receptors. The lack of effect on DA in the experiment may be attributable to a subthreshold concentration. All experiments were performed in the presence of CGP-35348 $(30 \mu \mathrm{M})$, SR-95531 $(10 \mu \mathrm{M})$, CNQX $(10 \mu \mathrm{M})$, and MK-801 $(10 \mu \mathrm{M})$. Drugs were superfused during the period indicated by the bars.

(D1 and D2) and $\alpha$-noradrenergic $\left(\alpha_{1}\right.$ and $\left.\alpha_{2}\right)$ receptors. In the vast majority of cases, these receptors appear to be segregated in different neurons because in most of our experiments, cells were either excited or inhibited (presumably after activation of D1/ $\alpha_{1}$ or D $2 / \alpha_{2}$ receptors, respectively), and they responded to only one type of agonist or antagonist. However, a few observations also indicate that multiple receptor types could be present in a minority of neurons.

Although most neurons that were sequentially tested for their reaction to DA and NE exhibited consistent reactions (i.e., they were either inhibited or excited by both amines), in a small number of cases (5 of 29) opposite reactions were detected (Fig. $6 C$ ). The most obvious interpretation of these effects is that these neurons express both D1 and D2 or $\alpha_{1}$ and $\alpha_{2}$ receptors or even a mix of the heterologous subtypes. In addition, complex pharmacological profiles were also observed in a small number of neurons. Two such cases are illustrated in Figure 10.

The neuron illustrated in Figure $10 A$ obviously expressed D2like receptors, given that its activity was completely suppressed by the D2 agonist, quinpirole, as it was by DA. However, when these $\mathrm{D} 2$ receptors were functionally blocked by $1 \mu \mathrm{M}$ sulpiride, DA, but not quinpirole, was still capable of inhibiting the firing rate, which indicates, on the basis of experiments described above, that DA was also acting on another receptor, presumably of the $\alpha_{2}$ subtype.

In another example illustrated in Figure $10 \mathrm{~B}$, a DA-induced increase of the firing rate was observed that obviously resulted from a stimulation of D1 receptors, given that the effect was blocked by SCH-23390. However, the same cell was inhibited by $\mathrm{NE}$, indicating that it presumably also expressed $\alpha_{2}$-adrenergic receptors.

These data thus clearly illustrate the fact that multiple receptors can be coexpressed in the same neurons. These events are relatively rare, however, and thus impossible to analyze systematically. It must be noted that in some cases the expression of multiple receptor (sub)types in the same cells may remain unnoticed and explain phenomena such as the lack of response of some neurons to DA. It is quite possible that some of the cells that we classified as nonresponding in our study $(<25 \%$ changes in firing rate) expressed receptor subtypes that mediate both an inhibition (D2 or $\alpha_{2}$ ) and an excitation (D1 or $\alpha_{1}$ ) of activity. A similar interpretation has been proposed recently for D1 and D2 receptors in the avian basal ganglia (Ding and Perkel, 2002). These effects could cancel out after application of a nonspecific agonist such as DA. Future studies should investigate the responses of these types of cell to specific dopaminergic and noradrenergic agonists to examine whether this interpretation could hold true in a limited number of cases.

\section{DISCUSSION}

The present study demonstrates that most neurons in the quail POA are dopaminoceptive. The inhibitory and excitatory effects of DA on POM neurons persisted in the presence of TTX (intracellular recordings) or GABAergic and glutamatergic antagonists (extracellular recordings), indicating that the DAinduced changes of the firing rates presumably result from direct effects of DA (synaptic transmission should be blocked in the presence of these compounds). Several lines of converging evidence indicate that a substantial fraction of DA effects (especially inhibitions) is mediated by activation of $\alpha$-noradrenergic receptors. (1) DA-induced inhibitions/excitations were not blocked by selective dopaminergic receptor antagonists (sulpiride/SCH23390) but were suppressed by selective $\alpha$-noradrenergic antagonists (yohimbine/prasozin). In support of this analysis, it must be noted that all compounds were used at pharmacologically relevant concentrations (usually 100-1000 times the $K_{\mathrm{i}}$ for the antagonists). The concentrations of sulpiride and SCH-23390 used were also found to completely block the effect of quinpirole and SKF38393 , respectively. (2) The similarity of the $\mathrm{pK}_{\mathrm{B}}$ values of yohimbine versus DA and NE demonstrated that yohimbine displaces with a similar potency the concentration-effect curves of the two amines. If anything, the $\alpha_{2}$-antagonist was slightly more potent versus DA than NE. This pharmacological technique unambiguously identifies the receptor involved in a functional effect (Kenakin, 1984) and demonstrates that DA activates $\alpha_{2}-$ noradrenergic receptors. (3) Finally, DBH inhibitors did not block DA effects, indicating that DA directly interacts with NE receptors. Together, these data strongly suggest that a large percentage of DA effects are mediated in the quail POM by interaction with $\alpha$-noradrenergic receptors.

The mechanism underlying the cross talk between DA and NE receptors remains unclear at this time. The present experiments suggest direct effects because the interaction is still observed after $\mathrm{DBH}$ inhibition, and the $\mathrm{pK}_{\mathrm{B}}$ of yohimbine indicates direct inter- 
actions with the same receptor of both DA and NE. The relatively similar structure of DA and NE could potentially explain the binding of both amines to the two receptor types. In the periphery, it is known that increasing plasma concentrations of DA will activate successively D1, $\beta_{1}$, and $\alpha_{1} / \alpha_{2}$ receptors. Relative concentrations to achieve these effects can be estimated at 1,3 , and 10 (Ooi and Colucci, 2001). Accordingly, the mean $\mathrm{EC}_{50}$ of DA for inhibitory effects was approximately eight times higher than for NE. Alternatively, recent studies indicate that transmembrane G-coupled receptors can form hetero-oligomers, the affinity and specificity of which are modified by the association. To our knowledge, this oligomerization has not been described for $\alpha$-noradrenergic receptors but concerns various receptors such as the dopaminergic D2 and somatostatin receptors (Rocheville et al., 2000) or the opioid and $\beta$-adrenergic receptors (Jordan et al., 2001). Future work should test whether this type of phenomenon explains the lack of specificity described here.

Inhibitory effects of DA mediated mainly by interactions with $\alpha$-noradrenergic receptors in the POA fit in well with autoradiographic investigations of catecholaminergic receptors in the quail and rat brain and with studies of the neurochemical controls of male sexual behavior. The POA receives dopaminergic and noradrenergic inputs (Simerly and Swanson, 1986; De Vries et al., 1988; Tillet et al., 1993; Balthazart and Absil, 1997), and in vivo dialysis studies demonstrate a testosterone-dependent release of DA in the male rat POA after sexual interactions (Hull et al., 1995; Putnam et al., 2001). However, the density of dopaminergic receptors is low in this area compared with the basal ganglia (Boyson et al., 1986; Dawson et al., 1986, 1988; Camps et al., 1989; Cortes et al., 1989; Ball et al., 1995). Major dopaminergic projections thus reach and affect an area with low dopaminergic receptor expression, but where, in contrast, $\alpha_{2}$-adrenergic receptors are very dense (Unnerstall et al., 1984; Ball et al., 1989). Effects of DA thus could be mediated in part by interactions with noradrenergic receptors. These data, however, do not exclude actions of DA mediated by DA receptors; infusions of specific DA agonists and antagonists in the POA indeed modulate expression of sexual behavior (Hull et al., 1989, 1992; Markowski et al., 1994), presumably through the activation of DA receptors that are also present in this area, as confirmed in the present study.

The POA projects to the mesencephalic central gray, a premotor center in the control of male sexual behavior (Murphy et al., 1999). Although the organization and control of this circuitry are obviously more complex (Hull et al., 2002), one action of DA in the POA is to suppress tonic inhibitory signals, thereby permitting full expression of copulation (Hull et al., 1997). This view is consistent with the present electrophysiological data, which reveal a widespread tonic activity in the POA and its inhibition after exposure to DA. In quail, TH-immunoreactive (ir) fibers surround aromatase-ir cells in the POA (Balthazart et al., 1998), and a large proportion of the aromatase-ir cells project to the central gray (Absil et al., 2001a). It thus could be argued that in the absence of testosterone and DA in the POA, male sexual behavior is blocked by outputs of these aromatase-expressing projection neurons. A single aromatase neuron projection to the central gray expressing $\alpha_{2}$-noradrenergic receptors could thus constitute a functional unit, explaining all available behavioral and neurochemical observations.

Several arguments suggest that the action of DA on NE receptors does not represent a specialization of the quail POM. First, catecholaminergic receptors in avian species, quail in particular, share many properties with mammalian receptors. The cloning of
D1- and D2-like receptors revealed high sequence homologies between avian and mammalian receptors (Demchyshyn et al., 1995; Cardinaud et al., 1998; Schnell et al., 1999). Autoradiographic studies reported similar distributions and binding specificity of avian and mammalian dopaminergic (Ball et al., 1995; Schnell et al., 1999; Levens et al., 2000) as well as $\alpha$-noradrenergic receptors (Bylund et al., 1988; Ball et al., 1989; Balthazart et al., 1989). Second, most of the drugs used here exert similar biological effects in mammals and birds, indicating that they conserve their functional specificity in the two vertebrate classes. This is namely the case of D1/D2 agonists and antagonists that produce similar effects on male sexual behavior of quail and rats (Bitran and Hull, 1987; Hull, 1995; Balthazart et al., 1997; Castagna et al., 1997). Third, scattered reports in the literature suggest that a cross talk between DA and NE receptors could actually take place even if these effects have not been characterized in great detail. In a study analyzing the excitatory and inhibitory effects of DA and NE on arcuate nucleus neurons, Moss and collaborators (1975) mentioned that the application of the $\alpha$-adrenergic receptor blocker, phentolamine, blocked both the DA and NE excitations. Similarly, activation by DA of noradrenergic receptors has been reported in different brain areas and periphery in mammals (Ruffolo et al., 1984; Malenka and Nicoll, 1986; Aguayo and Grossie, 1994; Lee et al., 1998; Edwards and Brooks, 2001). It has also been demonstrated that the same transporters can bind both NE and DA (Moron et al., 2002).

It thus seems likely that the cross talk characterized here is a widespread phenomenon that is specific to neither the avian brain nor the preoptic region. A part of the DA effects are mediated by DA receptors, but effects mediated by NE receptors seem the most frequent in the quail POA. This type of effect also appears to take place in the mammalian brain, but to our knowledge this is the first study demonstrating such an interaction in the CNS with classical pharmacological methods. An interesting conceptual consequence of this interaction is that the physiological effects of a transmitter may be more widespread than the sum of the effects of the activation of its specific receptors. This idea could be relevant to the field of schizophrenia. It has been suggested that anti-adrenergic properties might be important for understanding the properties of some antipsychotics, including clozapine (Baldessarini et al., 1992). Although it has been inferred that, besides DA systems, NE systems may also be dysfunctional in schizophrenia, our study suggests an alternative explanation: namely that dysf unctional DA systems may stimulate $\mathrm{NE}$ receptors in an inappropriate manner.

More generally, the present results confirm and extend previous studies suggesting a cross talk between DA and the noradrenergic receptors and transporter in the brain. For example, the reduction by DA of the slow afterhyperpolarization in hippocampal pyramidal neurons is blocked by propranolol ( $\beta$-adrenergic antagonist) but not mimicked by high concentrations of apomorphine (nonselective dopaminergic agonist) in the presence of the $\beta$-antagonist (Malenka and Nicoll, 1986). Studies using transgenic mice also demonstrated that the transporters for NE and DA lack specificity, so that in the prefrontal cortex, DA is mainly taken up by the NE transporter (Moron et al., 2002). Pharmacological methods clearly demonstrated here that DA and NE interact with the same receptors in the quail POM as suggested previously for the rat POA (Moss et al., 1975). Together these data may have important implications for our understanding of the neurobiology of brain monoaminergic systems and their pathophysiological role in CNS disorders. 


\section{REFERENCES}

Absil P, Das S, Balthazart J (1994) Effects of apomorphine on sexual behavior in male quail. Pharmacol Biochem Behav 47:77-88.

Absil P, Riters LV, Balthazart J (2001a) Preoptic aromatase cells project to the mesencephalic central gray in the male Japanese quail (Coturnix japonica). Horm Behav 40:369-383.

Absil P, Baillien M, Ball GF, Panzica G, Balthazart J (2001b) The control of preoptic aromatase activity by afferent inputs in Japanese quail. Brain Res Rev 37:38-58.

Aguayo LG, Grossie J (1994) Dopamine inhibits a sustained calcium current through activation of alpha adrenergic receptors and a GTPbinding protein in adult rat sympathetic neurons. J Pharmacol Exp Ther 269:503-508.

Bailhache T, Balthazart J (1993) The catecholaminergic system of the quail brain: immunocytochemical studies of dopamine $\beta$-hydroxylase and tyrosine hydroxylase. J Comp Neurol 329:230-256.

Baillien M, Balthazart J (1997) A direct dopaminergic control of aromatase activity in the quail preoptic area. J Steroid Biochem Mol Biol 63:99-113.

Baillien M, Foidart A, Balthazart J (1999) Regional distribution and control of tyrosine hydroxylase activity in the quail brain. Brain Res Bull 48:31-37.

Baldessarini RJ, Huston-Lyons D, Campbell A, Marsh E, Cohen BM (1992) Do central antiadrenergic actions contribute to the atypical properties of clozapine? Br J Psychiatry 160:12-16.

Ball GF, Nock B, McEwen BS, Balthazart J (1989) Distribution of alpha2-adrenergic receptors in the brain of the Japanese quail as determined by quantitative autoradiography: implications for the control of sexually dimorphic reproductive processes. Brain Res 491:68-79.

Ball GF, Casto JM, Balthazart J (1995) Autoradiographic localization of D1-like dopamine receptors in the forebrain of male and female Japanese quail and their relationship with immunoreactive tyrosine hydroxylase. J Chem Neuroanat 9:121-133.

Balthazart J, Absil P (1997) Identification of catecholaminergic inputs to and outputs from aromatase-containing brain areas of the Japanese quail by tract tracing combined with tyrosine hydroxylase immunocytochemistry. J Comp Neurol 382:401-428.

Balthazart J, Ball GF (1998a) The Japanese quail as a model system for the investigation of steroid-catecholamine interactions mediating appetitive and consummatory aspects of male sexual behavior. Annu Rev Sex Res 9:96-176.

Balthazart J, Ball GF (1998b) New insights into the regulation and function of brain estrogen synthase (aromatase). Trends Neurosci 21:243-249.

Balthazart J, Ball GF, McEwen BS (1989) An autoradiographic study of alpha1-adrenergic receptors in the brain of the Japanese quail (Coturnix coturnix japonica). Cell Tissue Res 258:563-568.

Balthazart J, Foidart A, Sante P, Hendrick JC (1992) Effects of alphamethyl-para-tyrosine on monoamine levels in the Japanese quail: sex differences and testosterone effects. Brain Res Bull 28:275-288.

Balthazart J, Castagna C, Ball GF (1997) Differential effect of D1 and D2 dopamine-receptor agonists and antagonists on appetitive and consummatory aspects of male sexual behavior in Japanese quail. Physiol Behav 62:571-580.

Balthazart J, Foidart A, Baillien M, Harada N, Ball GF (1998) Anatomical relationship between aromatase and tyrosine hydroxylase in the quail brain: double-label immunocytochemical studies. J Comp Neurol 391:214-226.

Balthazart J, Baillien M, Ball GF (2002) Interactions between aromatase (estrogen synthase) and dopamine in the control of male sexual behavior in quail. Comp Biochem Physiol [B] 132:37-55.

Bencsics A, Sershen H, Baranyi M, Hashim A, Lajtha A, Vizi ES (1997) Dopamine, as well as norepinephrine, is a link between noradrenergic nerve terminals and splenocytes. Brain Res 761:236-243.

Bitran D, Hull EM (1987) Pharmacological analysis of male sexual behavior. Neurosci Biobehav Rev 11:365-389.

Blackburn JR, Pfaus JG, Phillips AG (1992) Dopamine functions in appetitive and defensive behaviours. Prog Neurobiol 39:247-279.

Bowery B, Rothwell LA, Seabrook GR (1994) Comparison between the pharmacology of dopamine receptors mediating the inhibition of cell firing in rat brain slices through the substantia nigra pars compacta and ventral tegmental area. Br J Pharmacol 112:873-880.

Boyson SJ, McGonigle P, Molinoff PB (1986) Quantitative autoradiographic localization of the D1 and D2 subtypes of dopamine receptors in rat brain. J Neurosci 6:3177-3188.

Bungo T, Kawakami S-I, Ohgushi A, Sashihara K, Saito N, Sugahara K, Hasegawa S, Denbow DM, Furuse M (2001) Intracerebroventricular injection of fusaric acid attenuates the anorexia by glucagon-like peptide-1 in the neonatal chick. Pharmacol Biochem Behav 70:251-255.

Bylund DB, Rudeen PK, Petterborg LJ, Ray-Prenger C (1988) Identification of alpha2-adrenergic receptors in chicken pineal gland using $\left[{ }^{\circ} \mathrm{H}\right]$ rauwolscine. J Neurochem 51:81-86.

Camps M, Cortés R, Gueye B, Probst A, Palacios JM (1989) Dopamine receptors in human brain: autoradiographic distribution of D2 sites. Neuroscience 2:275-290.

Cardinaud B, Gibert JM, Sugamori KS, Vincent JD, Niznik HB, Vernier $P$ (1998) Comparative aspects of dopaminergic neurotransmission in vertebrates. Ann NY Acad Sci 839:47-52.

Castagna C, Ball GF, Balthazart J (1997) Effects of dopamine agonists on appetitive and consummatory male sexual behavior in Japanese quail. Pharmacol Biochem Behav 58:403-414.

Cornil CA, Balthazart J, Seutin V (2001) Electrophysiological and neurochemical characterization of neurons in the Japanese quail preoptic area. Soc Neurosci Abstr 27:2277.

Cortes R, Gueye B, Pazos A, Probst A, Palacios JM (1989) Dopamine receptors in human brain: autoradiographic distribution of D1 sites. Neuroscience 28:263-273.

Dawson TM, Gehhlert DR, Tyler McCabe R, Barnett A, Wamsley JK (1986) D1-dopamine receptors in the rat brain: a quantitative autoradiographic analysis. J Neurosci 6:2352-2365.

Dawson TM, Barone P, Sidhu A, Wamsley JK, Chase TN (1988) The D1 dopamine receptor in the rat brain: quantitative autoradiographic localization using an iodinated ligand. Neuroscience 26:83-100.

Demchyshyn LL, Sugamori KS, Lee FJS, Hamadanizadeh SA, Niznik HB (1995) The dopamine D1D receptor. Cloning and characterization of three pharmacological distinct D1-like receptors from Gallus domesticus. J Biol Chem 270:4005-4015.

De Vries GJ, Gonzales CL, Yahr P (1988) Afferent connections of the sexually dimorphic area of the hypothalamus of male and female gerbils. J Comp Neurol 271:91-105.

Ding L, Perkel DJ (2002) Dopamine modulates excitability of spiny neurons in the avian basal ganglia. J Neurosci 22:5210-5218.

Edwards RM, Brooks DP (2001) Dopamine inhibits vasopressin action in the rat inner medullary collecting duct via $\alpha 2$-adrenoceptors. J Pharmacol Exp Ther 298:1001-1006.

Foidart A, Reid J, Absil P, Yoshimura N, Harada N, Balthazart J (1995) Critical re-examination of the distribution of aromataseimmunoreactive cells in the quail forebrain using antibodies raised against human placental aromatase and against the recombinant quail, mouse or human enzyme. J Chem Neuroanat 8:267-282.

Hieble JP, Ruffolo RRJ (1996) Subclassification and nomenclature of alpha1- and alpha2-adrenoreceptors. In: Progress in drug research (Jucker E, ed), pp 82-130. Basel: Birkhäuser Verlag.

Hull EM (1995) Dopaminergic influences on male rat sexual behavior. In: Neurobiological effects of sex steroid hormones (Micevych PE, Hammer RPJ, eds), pp 234-253. Cambridge, UK: Cambridge UP.

Hull EM, Warner RK, Bazzett TJ, Eaton RC, Thompson JT, Scaletta LL (1989) D2/D1 ratio in the medial preoptic area affects copulation of male rats. J Pharmacol Exp Ther 251:422-427.

Hull EM, Eaton RC, Markowski VP, Moses J, Lumley LA, Loucks JA (1992) Opposite influence of medial preoptic D1 and D2 receptors on genital reflexes: implications for copulation. Life Sci 51:1705-1713.

Hull EM, Du J, Lorrain DS, Matuszewich L (1995) Extracellular dopamine in the medial preoptic area: implications for sexual motivation and hormonal control of copulation. J Neurosci 15:7465-7471.

Hull EM, Du J, Lorrain DS, Matuszewich L (1997) Testosterone, preoptic dopamine and copulation in rats. Brain Res Bull 44:327-333.

Hull EM, Meisel RL, Sachs BD (2002) Male sexual behavior. In: Hormones, brain and behavior (Pfaff DW, Arnold AP, Etgen AM, Fahrbach SE, Rubin RT, eds), pp 1-137. San Diego: Academic.

Jaber M, Robinson SW, Missale C, Caron MG (1996) Dopamine receptors and brain function. Neuropharmacology 35:1503-1519.

Jackson DM, Westlind-Danielsson A (1994) Dopamine receptors: molecular biology, biochemistry and behavioural aspects. Pharmacol Ther 64:291-369.

Jenkinson DH, Barnard EA, Hoyer D, Humphrey PPA, Leff P, Shankley NP (1995) International union of pharmacology committee on receptor nomenclature and drug classification. IX. Recommendations on terms and symbols in quantitative pharmacology. Pharmacol Rev 47:255-266.

Jordan BA, Trapaidze N, Gomes I, Nivarthi R, Devi LA (2001) Oligomerization of opioid receptors with $\beta 2$-adrenergic receptors: a role in trafficking and mitogen-activated protein kinase activation. Proc Natl Acad Sci USA 98:343-348.

Kenakin TP (1984) The classification of drugs and drug receptors in isolated tissues. Pharmacol Rev 36:165-222.

Lacey MG, Mercuri NB, North RA (1987) Dopamine acts on $\mathrm{D}_{2}$ receptors to increase potassium conductance in neurones of the rat substantia nigra zona compacta. J Physiol (Lond) 392:397-416.

Laruelle M, Abi-Dargham A (1999). Dopamine as the wind of the psychotic fire: new evidence from brain imaging studies. J Psychopharmacol 13:358-371.

Lee TL, Hsu CT, Yen ST, Lai CW, Cheng JT (1998) Activation of beta3-adrenoceptors by exogenous dopamine to lower glucose uptake into rat adipocytes. J Auton Nerv Syst 74:86-90.

Levens N, Green TA, Akins CK, Bardo MT (2000) Dopamine D2-like receptor binding in the brain of male Japanese quail (Coturnix japonica). Neurosci Lett 296:77-80. 
Malenka RC, Nicoll RA (1986) Dopamine decreases in the calciumactivated afterhyperpolarization in hippocampal CA1 pyramidal cells. Brain Res 379:210-215.

Markowski VP, Eaton RC, Lumley LA, Moses J, Hull EM (1994) A D1 agonist in the MPOA facilitates copulation in male rats. Pharmacol Biochem Behav 47:483-486.

Meisel RL, Sachs BD (1994) The physiology of male sexual behavior. In: The Physiology of reproduction, Vol 2, Ed 2 (Knobil E, Neill JD, eds), pp 3-105. New York: Raven.

Meyer-Lindenberg A, Miletich RS, Kohn PD, Esposito G, Carson RE, Quarantelli M, Weinberger DR, Berman KF (2002) Reduced prefrontal activity predicts exaggerated striatal dopaminergic function in schizophrenia. Nat Neurosci 5:267-271.

Missale C, Nash SR, Robinson SW, Jaber M, Caron MG (1998) Dopamine receptors: from structure to function. Physiol Rev 78:189-225.

Moron JA, Brockington A, Wise RA, Rocha BA, Hope BT (2002) Dopamine uptake through norepinephrine transporter in brain regions with low levels of the dopamine transporter: evidence from knock-out mouse lines. J Neurosci 22:389-395.

Moss RL, Kelly MJ, Riskind P (1975) Tuberoinfundibular neurons: dopaminergic and norepinephrinergic sensitivity. Brain Res 89:265-277.

Murphy AZ, Rizvi TA, Ennis M, Shipley MT (1999) The organization of preoptic-medullary circuits in the male rat: evidence for interconnectivity of neural structures involved in reproductive behavior, antinociception and cardiovascular regulation. Neuroscience 91:1103-1116.

Nagatsu T, Kuzuya H, Hidaka H (1967) Inhibition of dopamine betahydroxylase by sulfhydryl compounds and the nature of the natural inhibitors. Biochim Biophys Acta 139:319-327.

Nagatsu T, Hidaka H, Kuzuya H, Takeya K, Umezawa H, Takeuchi T, Suda H (1970) Inhibition of dopamine beta-hydroxylase by fusaric acid (5-butylpicolinic acid) in vitro and in vivo. Biochem Pharmacol 19:35-44.

Ooi H, Colucci WS (2001) Pharmacological treatment of heart failure. In: The pharmacological basis of therapeutics, Ed 10 (Hardman JG, Limbird LE, Gilman AG, eds), p 901. New York: McGraw-Hill.

Ottinger MA, Balthazart J (1987) Brain monoamines in Japanese quail: effects of castration and steroid replacement therapy. Behav Proc 14:197-216.

Panzica GC, Viglietti-Panzica C, Balthazart J (1996) The sexually dimorphic medial preoptic nucleus of quail: a key brain area mediating steroid action on the male sexual behavior. Front Neuroendocrinol 17:51-125.

Putnam SK, Du JF, Sato S, Hull EM (2001) Testosterone restoration of copulatory behavior correlates with medial preoptic dopamine release in castrated male rats. Horm Behav 39:216-224.

Rocheville M, Lange DC, Kumar U, Patel SC, Patel RC, Patel YC (2000) Receptors for dopamine and somatostatin: formation of heterooligomers with enhanced functional activity. Science 288:154-157.

Ruffolo RRJ, Goldberg MR, Morgan EL (1984) Interactions of epinephrine, norepinephrine, dopamine and their corresponding alpha-methylsubstituted derivatives with alpha and adrenoreceptors in the pithed rat. J Pharmacol Exp Ther 230:595-600.

Ruskin DN, Rawji SS, Walters JR (1998) Effects of full D1 dopamine receptor agonists on firing rates in the globus pallidus and substantia nigra pars compacta in vivo: tests for D1 receptor selectivity and comparisons to the partial agonist SKF 38393. J Pharmacol Exp Ther 286:272-281.

Schnell SA, You S, Foster DN, El Halawani ME (1999) Molecular cloning and tissue distribution of an avian D2 dopamine receptor mRNA from the domestic turkey (Meleagris gallopavo). J Comp Neurol 407:543-554.

Seutin V, Verbanck P, Massotte L, Dresse A (1990) Evidence for the presence of $N$-methyl-D-aspartate receptors in the ventral tegmental area of the rat: an electrophysiological study. Brain Res 514:147-150.

Shanker G, Allen JW, Mutkus LA, Aschner M (2001) The uptake of cysteine in cultured primary astrocyte and neurons. Brain Res 902:156-163.

Simerly RB, Swanson LW (1986) The organization of neural inputs to the medial preoptic nucleus of the rat. J Comp Neurol 246:312-342.

Stoof JC, Kebabian JW (1981) Opposing roles for D-1 and D-2 dopamine receptors in efflux of cyclic AMP from rat neostriatum. Nature 294:366-368

Sugamori KS, Demchyshyn LL, Chung M, Niznik HB (1994) D1A, D1B, and D1C dopamine receptors from Xenopus laevis. Proc Natl Acad Sci USA 91:10536-10540.

Terry LC, Craig R (1985) Cysteamine effects on monoamines, dopamine-beta-hydroxylase and the hypothalamic-pituitary axis. Neuroendocrinology 41:467-475.

Tillet Y, Batailler M, Thibault J (1993) Neuronal projections to the medial preoptic area of the sheep, with special reference to monoaminergic afferents: immunohistochemical and retrograde tract tracing studies. J Comp Neurol 330:195-220.

Unnerstall JR, Kopajtic TA, Kuhar MJ (1984) Distribution of $\alpha 2$ agonist binding sites in the rat and human central nervous system: analysis of some functional, anatomic correlates of the pharmacological effects of clonidine and related adrenergic agents. Brain Res Rev 7:69-101. 